\title{
BMJ Open Are mass-media campaigns effective in preventing drug use? A Cochrane systematic review and meta-analysis
}

\author{
Elias Allara, ${ }^{1,2}$ Marica Ferri, ${ }^{3}$ Alessandra Bo, ${ }^{3}$ Antonio Gasparrini, ${ }^{4}$ \\ Fabrizio Faggiano ${ }^{1}$
}

To cite: Allara E, Ferri M, Bo A, et al. Are mass-media campaigns effective in preventing drug use? A Cochrane systematic review and meta-analysis. BMJ Open 2015;5: 0007449.

doi:10.1136/bmjopen-2014007449

\section{- Prepublication history and additional material is available. To view please visit the journal (http://dx.doi.org/ 10.1136/bmjopen-2014- 007449).}

Note: This article is based on a Cochrane Review published in the Cochrane Database of Systematic Reviews (CDSR) 2013, Issue 6, DOI: 0.1002/ 14651858.CD009287.pub2 (see http://www.

thecochranelibrary.com for information). Cochrane Reviews are regularly updated as new evidence emerges and in response to feedback, and the CDSR should be consulted for the most recent version of the review.

Received 15 December 2014 Revised 25 March 2015 Accepted 26 March 2015

\section{CrossMark}

For numbered affiliations see end of article.

Correspondence to

Dr Elias Allara;

elias.allara@med.unipmn.it

\section{ABSTRACT}

Objective: To determine whether there is evidence that mass-media campaigns can be effective in reducing illicit drug consumption and the intent to consume.

Design: Systematic review of randomised and nonrandomised studies.

Methods: We searched four electronic databases (MEDLINE, EMBASE, ProQuest Dissertations \& Theses A\&I and CENTRAL) and further explored seven additional resources to obtain both published and unpublished materials. We appraised the quality of included studies using standardised tools. We carried out meta-analyses of randomised controlled trials and a pooled analysis of interrupted time-series and controlled before-and-after studies.

Results: We identified 19 studies comprising 184811 participants. Pooled analyses and narrative synthesis provided mixed evidence of effectiveness. Eight interventions evaluated with randomised controlled trials leaned towards no evidence of an effect, both on drug use (standardised mean difference (SMD) -0.02 ; $95 \% \mathrm{Cl}-0.15$ to 0.12 ) and the intention to use drugs (SMD $-0.07 ; 95 \% \mathrm{Cl}-0.19$ to 0.04 ). Four campaigns provided some evidence of beneficial effects in preventing drug use and two interventions provided evidence of iatrogenic effects.

Conclusions: Studies were considerably heterogeneous in type of mass-media intervention, outcome measures, underlying theory, comparison groups and design. Such factors can contribute to explaining the observed variability in results. Owing to the risk of adverse effects, caution is needed in disseminating mass-media campaigns tackling drug use. Large studies conducted with appropriate methodology are warranted to consolidate the evidence base.

\section{INTRODUCTION}

Mass-media campaigns are a powerful means for disseminating health promotion messages. A wide and diverse audience can be reached through television commercials, the Internet, mobile phones, newspapers and

\section{Strengths and limitations of this study}

- This systematic review is based on an expanded evidence base of both published and unpublished findings and aims to determine whether mass-media campaigns can be effective in preventing the use of or intention to use illicit drugs.

- Pooled analyses of eight mass-media interventions provide no evidence of an effect on drug use or intention to use illicit drugs. Four interventions provide evidence of beneficial effects. Two interventions provide evidence of iatrogenic effects.

- Owing to the paucity and inconsistency of available evidence, we cannot draw general conclusions as to whether mass-media interventions are effective in preventing the use of or intention to use illicit drugs.

- This review provides an insight into research gaps around the impact of mass-media drug prevention interventions and can serve to highlight that new campaigns should be implemented in the framework of rigorous evaluation studies, in order to avoid dissemination of interventions that are ineffective or have unintended effects.

roadside advertising hoardings. In the field of drug addiction and dependence, advertisements may contribute to shaping patterns of drug use and the intention to use drugs, as well as modifying mediators such as awareness, knowledge and attitudes about drugs.

However, ethical and economic considerations are often raised. Mass-media campaigns -unlike other health interventions-are imposed on populations that have not consented to their implementation. ${ }^{1}$ This is a considerable ethical issue in modern, personcentred public health, where taking decisions shared with the public is essential for promoting behaviour change. Second, massmedia campaigns can be very expensive, especially when implemented at the national or state level. Large-scale purchasing of 
public service announcement time during popular shows and broad dissemination via printed media are often accessible only to governmental institutions. For example, the first and second versions of the US Office of National Drug Control Policy's National Youth Anti-Drug Media Campaign cost 2.7 billion dollars over more than 10 years. ${ }^{2}$ Although such campaigns underwent careful evaluation, most mass-media interventions are not developed in compliance with the classical circle of public health, which consists in designing interventions based on evidence and in evaluating their impact.

A systematic review of the studies assessing media campaigns aiming to prevent use of illicit drugs can inform future strategies and help design effective campaigns. The objective of this review is to assess the effectiveness of mass-media campaigns in preventing or reducing drug use or the intention to use illicit drugs among young people.

\section{METHODS}

We conducted this systematic review in accordance with the Preferred Reporting Items for Systematic Reviews and Meta-Analyses (PRISMA) ${ }^{3}$ statement and with the procedures specified in a previously published protocol. ${ }^{4}$ As described in detail previously, ${ }^{4}$ we systematically searched four electronic databases: MEDLINE (1966 to 29 January 2013), EMBASE (1974 to 30 January 2013), ProQuest Dissertations and Theses A\&I (1861 to 3 February 2013) and CENTRAL (2013, Issue 1). Search strategies are available as supplementary files (see online supplementary appendix 1). We further explored seven additional resources to obtain both published and unpublished materials: four websites of registered studies (ie, http:// www.controlled-trials.com, http://apps.who.int/trialsearch/, http://clinicaltrials.gov/, https://eudract.emea.europa. $\mathrm{eu} /$ ), references embedded in book chapters, references included in the annual national reports written by EMCDDA national focal points and any publications recommended by prominent researchers in the field. We did not set any constraints, such as language or time, to our search.

\section{Selection criteria}

As described in detail previously, ${ }^{4}$ we considered studies involving participants under the age of 26 and evaluating mass-media campaigns explicitly aimed at influencing the use or intention to use illicit drugs. ${ }^{5}$ The following were deemed acceptable comparison groups: (1) no intervention; (2) community-based or schoolbased drug prevention programmes; (3) lower exposure to intervention; (4) time before exposure to intervention. We included randomised controlled trials (RCTs), cohort studies, interrupted time-series (ITS) studies and controlled before and after (CBA) studies providing evidence on drug use or intention not to use, to reduce use or to stop use of illicit drugs.
Two authors independently inspected search hits by reading titles and abstracts and assessed studies for inclusion. Any disagreement was solved by consensus. Multiple publications pertaining to the same study were collated as one single study.

\section{Quality Appraisal}

Four authors independently performed quality assessments, and any disagreement was solved by consensus. We contacted study authors whenever information was missing or unclear.

We used standardised assessment tools for each study design-details are available as supplementary materials (see online supplementary appendix 2). For RCTs, we used the Cochrane Collaboration Risk of Bias assessment tool. ${ }^{6}$ For cohort studies, we followed the Scottish Intercollegiate Guidelines Network (SIGN) Quality Criteria. ${ }^{7}$ For ITS and CBA studies, we used the tool recommended by the Cochrane Effective Practice and Organisation of Care Group. ${ }^{8}$

\section{Statistical analysis}

As for RCTs, we performed a random effects meta-analysis to estimate the pooled effect of massmedia interventions on drug use while accounting for between-study heterogeneity, as described in detail previously. ${ }^{4}$ We carried out a fixed effects meta-analysis to estimate the pooled intervention effect on intention to use drugs. We tested between-study heterogeneity using the $\chi^{2}$ test and the $\mathrm{I}^{2}$ statistic. A $\mathrm{p}$ value lower than 0.10 in the $\chi^{2}$ test and an $\mathrm{I}^{2}$ statistic higher than $50 \%$ suggested evidence of heterogeneity. Since most studies assessed their outcome variables with different scales, we used standardised mean difference (SMD) as the summary measure of choice. SMDs were used for both drug use and intention to use drugs and were calculated by dividing the difference in mean outcome between groups by the SD of outcome between participants. ${ }^{6}$ SMDs and their SEs were then pooled in a meta-analysis performed with RevMan. ${ }^{9}$ For two clustered RCTs, ${ }^{10}{ }^{11}$ we inflated SEs to account for within-cluster correlations. ${ }^{6}$

We pooled the effect estimates of the Meth Project studies using mixed effects logistic regression. ${ }^{12-16}$ An ITS design was applied for estimating the differences in prevalence of methamphetamine use before and after the Meth Project intervention, adjusting for any underlying temporal trend. We fitted the following model: $\operatorname{logit}\left(\right.$ use $\left._{i j}\right)=\beta_{0}+u_{0 j}+\beta_{1}$ time $_{i}+\beta_{2}$ age $_{i}+\beta_{3}$ interv $_{i}+\beta_{4}$ age exinterv ${ }_{i}$, in which use was prevalence of methamphetamine use, time was a continuous variable, age and intervention were two-level categorical variables, $\mathrm{u}_{0 \mathrm{j}}$ was a random intercept and we allowed log odds of methamphetamine use to vary randomly by each jth state. ${ }^{17}$ The relatively few data points did not allow exploration of more complex models, for example, the temporal trend could not be assumed to vary randomly across states. 


\section{RESULTS}

Out of 18343 titles and abstracts, we selected 24 papers corresponding to 19 individual studies (figure 1).

\section{Study Characteristics}

Overall, 184811 participants were included, with most studies comprising participants who were aged between 10 and 19 years (table 1). Although most studies included both boys and girls, two studies focused on girls. ${ }^{18} 19$ One study considered Asian-Americans as the only ethnic group eligible for inclusion, ${ }^{18}$ while the other study did not focus on any specific ethnic groups. Seventeen studies were conducted in the USA, one in the USA and Canada ${ }^{19}$ and one in Australia. ${ }^{11}$

Eleven studies $(58 \%)$ evaluated multicomponent interventions, 3 regarding radio/television and printed advertising, ${ }^{10} 20$ and 8 regarding radio and television commercials, printed advertisements and Internet advertising. ${ }^{212-16} 2223$ Eight studies evaluated standalone interventions, four consisting in radio and television commercials, ${ }^{24-27}$ and four in Internet-based interventions. ${ }^{11} 181928$ The included studies in this review were grounded in a wide range of underlying theories (table 1).

Comparison groups varied considerably across studies. For thirteen studies (68\%), the comparison group consisted in no exposure to any intervention. Four studies compared high exposure versus low exposure to the same mass media intervention. ${ }^{2}{ }^{21-23}$ For one study, the comparison group consisted in the standard drug education curriculum. ${ }^{11}$ One study had four study arms consisting either in another intervention or no intervention. ${ }^{26}$

Eight studies were conducted in an experimental setting by explicitly inviting participants and these studies were randomised controlled trials (RCTs)..$^{10} 111819$ 25-28 Ten studies were conducted in a field setting without explicitly inviting participants, as would usually happen with most mass-media campaigns. Of them, 2 were cohort studies, ${ }^{22} 236$ were ITS $^{2}{ }^{12}{ }^{14-16} 24$ and 2 were CBA studies. ${ }^{13}{ }^{20}$ One study had a double design as it was conducted in an experimental setting with an RCT design, and in a field setting with a cohort design. ${ }^{21}$ When specified, follow-up varied from 6 months ${ }^{19} 28$ to 4.7 years. ${ }^{22}$

\section{Study quality}

On the whole, the quality of the RCTs is acceptable (table 2). As described in detail previously, ${ }^{4}$ the strongest domain appears to be the risk of attrition bias and the weakest domain the risk of selection bias (unclear description of the randomisation procedure). In one paper, findings of secondary outcomes were reported only as a predictor of the primary outcome, and the paper concerned was deemed at high risk for reporting bias. $^{19}$
Figure 1 PRISMA flow diagram. Adapted from a previous publication. ${ }^{4}$






\begin{tabular}{|c|c|c|c|c|c|c|c|c|}
\hline Study & Underpinning theory & $\begin{array}{l}\text { Design } \\
\text { (goal) }\end{array}$ & Intervention & Comparison & Primary outcome & Secondary outcome(s) & $\begin{array}{l}\text { Analysis } \\
\text { sample }\end{array}$ & $\begin{array}{l}\text { Follow-up } \\
\text { (total time) } \\
\text { (months) }\end{array}$ \\
\hline $\begin{array}{l}\text { Polansky et al } \\
1999^{25}\end{array}$ & Decision theory & $\mathrm{RCT}(\mathrm{E})$ & PSA & Other & - & $\begin{array}{l}\text { Intention to use; attitudes; } \\
\text { knowledge and disposition to } \\
\text { select socially appropriate } \\
\text { responses }\end{array}$ & 312 & NA (NS) \\
\hline $\begin{array}{l}\text { Miller et al } \\
2000^{20}\end{array}$ & Self-regulation theory & CBA (F) & PSA; printed & $\begin{array}{l}\text { No } \\
\text { intervention }\end{array}$ & $\begin{array}{l}\text { Use of drugs (incl. } \\
\text { cannabis and cocaine) }\end{array}$ & $\begin{array}{l}\text { Risk perception; problems related } \\
\text { to drug use }\end{array}$ & 1024 & $12(18)$ \\
\hline $\begin{array}{l}\text { Palmgreen } \\
\text { et al } 2001^{24}\end{array}$ & $\begin{array}{l}\text { Influence of sensation-seeking } \\
\text { on drug use }\end{array}$ & ITS (F) & PSA & $\begin{array}{l}\text { No } \\
\text { intervention }\end{array}$ & $\begin{array}{l}\text { Past } 30 \text {-day use of } \\
\text { marijuana }\end{array}$ & - & 6371 & NA (32) \\
\hline $\begin{array}{l}\text { Yzer et al } \\
2003^{26}\end{array}$ & $\begin{array}{l}\text { Theories of behavioural } \\
\text { change: persuasion effects }\end{array}$ & $\mathrm{RCT}(\mathrm{E})$ & PSA & $\begin{array}{l}\text { No } \\
\text { intervention; } \\
\text { other }\end{array}$ & - & $\begin{array}{l}\text { Intention to use marijuana; } \\
\text { attitude; perceptions about } \\
\text { marijuana }\end{array}$ & 418 & NA (NS) \\
\hline $\begin{array}{l}\text { Slater et al } \\
2006^{10}\end{array}$ & $\begin{array}{l}\text { Social-ecological framework } \\
\text { (norms and expectations } \\
\text { influence drug use) }\end{array}$ & $\mathrm{RCT}(\mathrm{E})$ & PSA; printed & $\begin{array}{l}\text { No } \\
\text { intervention }\end{array}$ & $\begin{array}{l}\text { Lifetime and past 30-day } \\
\text { use of marijuana }\end{array}$ & - & 4216 & $24(42)$ \\
\hline $\begin{array}{l}\text { Zhao et al } \\
2006^{27}\end{array}$ & Normative beliefs & $\mathrm{RCT}(\mathrm{E})$ & PSA & $\begin{array}{l}\text { No } \\
\text { intervention }\end{array}$ & - & $\begin{array}{l}\text { Intention to use; beliefs towards } \\
\text { marijuana; social norms }\end{array}$ & 435 & NS (NS) \\
\hline Hornik $2006^{22}$ & Unclear & Cohort (F) & $\begin{array}{l}\text { PSA; printed; } \\
\text { internet }\end{array}$ & $\begin{array}{l}\text { Lower } \\
\text { exposure }\end{array}$ & $\begin{array}{l}\text { Lifetime, past year, and } \\
\text { past } 30 \text {-day use of } \\
\text { marijuana }\end{array}$ & $\begin{array}{l}\text { Intention to use; attitudes and } \\
\text { self-efficacy; perceptions and } \\
\text { social norms }\end{array}$ & 8117 & $56(58)$ \\
\hline $\begin{array}{l}\text { Scheier and } \\
\text { Grenard } \\
2010^{23}\end{array}$ & Social marketing & Cohort (F) & $\begin{array}{l}\text { PSA; printed; } \\
\text { internet }\end{array}$ & $\begin{array}{l}\text { Lower } \\
\text { exposure }\end{array}$ & $\begin{array}{l}\text { Past } 12 \text {-month cannabis } \\
\text { intoxications }\end{array}$ & - & 2515 & NA (48) \\
\hline $\begin{array}{l}\text { Schwinn et al } \\
2010^{19}\end{array}$ & Social learning theory & $\mathrm{RCT}(\mathrm{E})$ & Internet & $\begin{array}{l}\text { No } \\
\text { intervention }\end{array}$ & $\begin{array}{l}\text { Past 30-day substance } \\
\text { use }\end{array}$ & - & 236 & 6 (NS) \\
\hline $\begin{array}{l}\text { Lee et al } \\
2010^{28}\end{array}$ & Readiness to change & $\mathrm{RCT}(\mathrm{E})$ & Internet & $\begin{array}{l}\text { No } \\
\text { intervention }\end{array}$ & $\begin{array}{l}\text { Past 90-day use of } \\
\text { marijuana }\end{array}$ & $\begin{array}{l}\text { Intention to change marijuana use; } \\
\text { consequences }\end{array}$ & 341 & 6 (NS) \\
\hline $\begin{array}{l}\text { Fang et al } \\
2010^{18}\end{array}$ & Family-oriented & $\mathrm{RCT}(\mathrm{E})$ & Internet & $\begin{array}{l}\text { No } \\
\text { intervention }\end{array}$ & $\begin{array}{l}\text { Past } 30 \text {-day use of } \\
\text { marijuana }\end{array}$ & Intention to use marijuana & 216 & $6.25(16)$ \\
\hline $\begin{array}{l}\text { Newton et al } \\
2010^{11}\end{array}$ & Social influence approach & $\mathrm{RCT}(\mathrm{E})$ & Internet & Other & Use of cannabis & $\begin{array}{l}\text { Cannabis knowledge; attitudes; } \\
\text { related harms }\end{array}$ & 724 & $12(21)$ \\
\hline $\begin{array}{l}\text { Meth Project } \\
\text { studies }^{12-16}\end{array}$ & $\begin{array}{l}\text { Perception of risk and } \\
\text { perception of social } \\
\text { disapproval are correlated with } \\
\text { drug consumption }\end{array}$ & $\begin{array}{l}4 \text { ITS and } \\
1 \text { CBA (F) }\end{array}$ & $\begin{array}{l}\text { PSA; printed; } \\
\text { internet }\end{array}$ & $\begin{array}{l}\text { No } \\
\text { intervention }\end{array}$ & $\begin{array}{l}\text { Past 30-day use of } \\
\text { methamphetamine }\end{array}$ & $\begin{array}{l}\text { Attitudes on methamphetamine } \\
\text { and other drugs; perceptions; } \\
\text { information sources and } \\
\text { advertising awareness; }\end{array}$ & 26405 & $\begin{array}{l}\text { NA } \\
\text { (Colorado 26; } \\
\text { Georgia 18; } \\
\text { Hawaii 25; } \\
\text { Idaho 40; } \\
\text { Wyoming } 34 \text { ) }\end{array}$ \\
\hline $\begin{array}{l}\text { Slater et al } \\
2011^{21}\end{array}$ & $\begin{array}{l}\text { Autonomy and aspiration } \\
\text { perceptions as mediators of } \\
\text { marijuana use }\end{array}$ & $\begin{array}{l}\mathrm{RCT}(\mathrm{E}) \\
\text { Cohort }(\mathrm{F})\end{array}$ & PSA; printed & $\begin{array}{l}\text { Lower } \\
\text { exposure }\end{array}$ & $\begin{array}{l}\text { Lifetime, past } 90 \text {-day } \\
\text { and past } 30 \text {-day use of } \\
\text { marijuana }\end{array}$ & $\begin{array}{l}\text { Autonomy and aspiration } \\
\text { inconsistent with marijuana use }\end{array}$ & 3236 & $24(42)$ \\
\hline $\begin{array}{l}\text { Carpenter and } \\
\text { Pechmann } \\
2011^{2}\end{array}$ & $\begin{array}{l}\text { Unclear; evaluated many } \\
\text { heterogeneous mass-media } \\
\text { campaigns }\end{array}$ & ITS (F) & $\begin{array}{l}\text { PSA; printed; } \\
\text { internet }\end{array}$ & $\begin{array}{l}\text { Lower } \\
\text { exposure }\end{array}$ & $\begin{array}{l}\text { Past 30-day and lifetime } \\
\text { use of marijuana }\end{array}$ & - & 130245 & NA (36) \\
\hline
\end{tabular}

CBA, controlled before and after; Cohort, prospective cohort: $\mathrm{E}$, experimental/efficacy setting; $\mathrm{F}$, field/effectiveness setting; ITS, interrupted time-series; Lower exposure, lower exposure to same intervention; NA, not applicable; NS, not specified; Other, other intervention or different combination of same intervention; PSA, public service announcement (eg, television/radio); RCT, randomised controlled trial. 
Table 2 Risk of bias of included studie

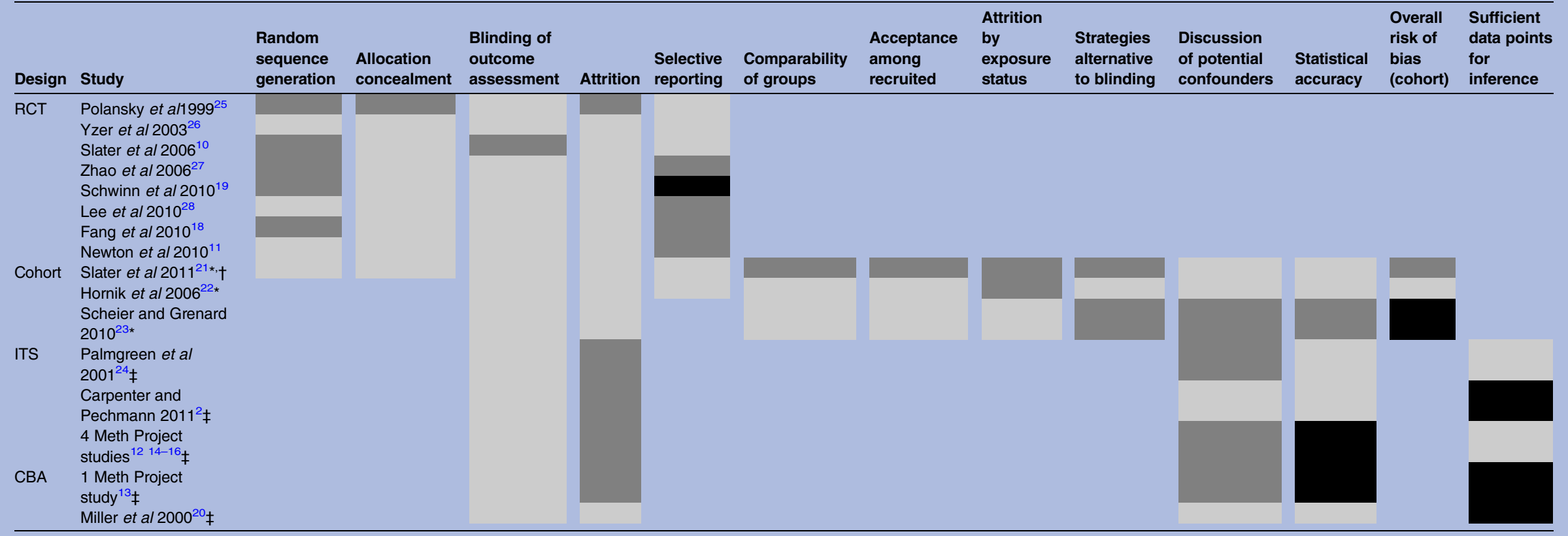

Study quality was appraised with three different tools depending on study design. Redundant or similar items were collapsed. The 'the intervention was independent of other changes' item of the ITS checklist was considered equivalent to the 'discussion of potential confounder' item for cohort studies, the 'formal test for trend' ITS item was considered equivalent to the 'statistical accuracy' item for cohort studies and the 'completeness of data set' ITS item was considered equivalent to the 'attrition' item for RCT and cohort studies.

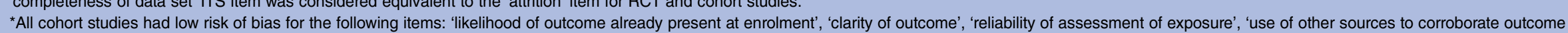
"All cohort studies had low risk of bias for the

measure', and 'multiple measure of exposure'.

fAll ITS studies and the CBA study had low risk of bias for the following items: 'intervention unlikely to affect data collection', and 'reliable primary outcome measure(s)'.

, high risk of bias; _ low risk of bias; _ unclear risk of bias; CBA, controlled before and after; Cohort, prospective cohort; ITS, interrupted time-series; RCT, randomised controlled trial; White, not applicable. 
All cohort studies focused on a clear and appropriate question. Subgroup comparisons between participants and dropouts were carried out in only one study. ${ }^{23}$ The same study, however, failed to control for potential confounders.

The proportion of participants with no missing data was reported in only one controlled CBA study. ${ }^{20}$ Potential confounders were accounted for in only one ITS study ${ }^{2}$ and one CBA study. ${ }^{20} \mathrm{~A}$ formal test of trend was not performed in the five Meth Project studies. ${ }^{12-16}$ One ITS study ${ }^{2}$ and the two CBA studies ${ }^{13}{ }^{20}$ had three or less data points, which are generally considered insufficient for drawing reliable conclusions with regard to intervention effectiveness.

\section{EFFECTS OF MASS-MEDIA CAMPAIGNS}

\section{Use of illicit drugs}

\section{Experimental studies}

Pooled analyses of five RCTs ${ }^{10} 11 \quad 181928$ comprising $\mathrm{n}=5470$ subjects showed no evidence $(\mathrm{p}=0.79)$ of an effect of mass-media campaigns in modifying use of illicit drugs (standardised mean difference (SMD) -0.02 ; $95 \%$ CI -0.15 to 0.12 ; figure 2 and table 3 ). There was some evidence $(p=0.020)$ of heterogeneity between studies.

The RCT part of a mixed RCT-cohort study ( $\mathrm{n}=3236)$ found evidence of effectiveness $(p=0.026)$ for a mediacommunity intervention (OR $0.60 ; 95 \%$ CI 0.38 to 0.94 ; table 3$).{ }^{21}$

\section{Field studies}

Two studies found that the Office of National Drug Control Policy (ONDCP) National Youth Anti-Drug Media Campaign (first version) increased use of illicit drugs among adolescents (table 3). One study ( $\mathrm{n}=3529)$ reported a significant increase in past year-use of marijuana (OR 1.21; 95\% CI 1.19 to 1.65$){ }^{22}$ The other study $(\mathrm{n}=2515)$ found some evidence (' $\mathrm{p}<0.05$ ') of an iatrogenic effect among those aged 15-18 (mean change $=0.144$ ), while there was no evidence ('p $>0.05$ ') of an effect among those aged 13-14 (mean change $=-0.022){ }^{23}$

The revamped version of the same ONDCP campaign, Above the Influence, was found effective in a mixed RCT-cohort study ( $\mathrm{n}=3236)$, whose cohort part found strong evidence $(p<0.001)$ of effectiveness (OR 0.26; $95 \%$ CI 0.19 to 0.35$).{ }^{21}$ On a similar note were the findings of an ITS study ( $n=130$ 245) which evaluated Above the Influence and found evidence of reductions in marijuana use in the past month (OR $0.67 ; 95 \%$ CI 0.52 to 0.87 ) among eighth-grade girls. ${ }^{2}$

The pooled findings of the five Meth Project studies ( $n=26$ 273) suggested no evidence of a change in pastmonth use of methamphetamine among subjects aged 12-17 (OR 1.16; 95\% CI 0.83 to 1.61 ), nor among those aged $18-24$ (OR $1.63 ; 95 \%$ CI 0.70 to 3.79 ) (figure 3A and table 3$)$. There was, however, evidence $(p=0.001)$ of a reduction in past-year use of methamphetamine among those aged $12-17$ (OR 0.59 ; 95\% CI 0.43 to 0.81 ), while there was no evidence of a similar effect among those aged $18-24$ (OR $0.70 ; 95 \%$ CI 0.34 to 1.45 ; figure $3 \mathrm{~B}$ and table 3 ).

One ITS ( $\mathrm{n}=6371)$ showed evidence of effectiveness for past 30-day use of marijuana among high sensation seekers $(p=0.001$ for the Fayette sample, $p=0.001$ for the first campaign in the Knox sample, $\mathrm{p}=0.002$ for the second campaign in the Knox sample). ${ }^{24}$

One CBA study found an increase in use of LSD ('p $<0.001$ '; table 3 ) while no evidence (' $p>0.05$ ') of differences was found for marijuana, cocaine, amphetamine and heroin. ${ }^{20}$

A

Drug use

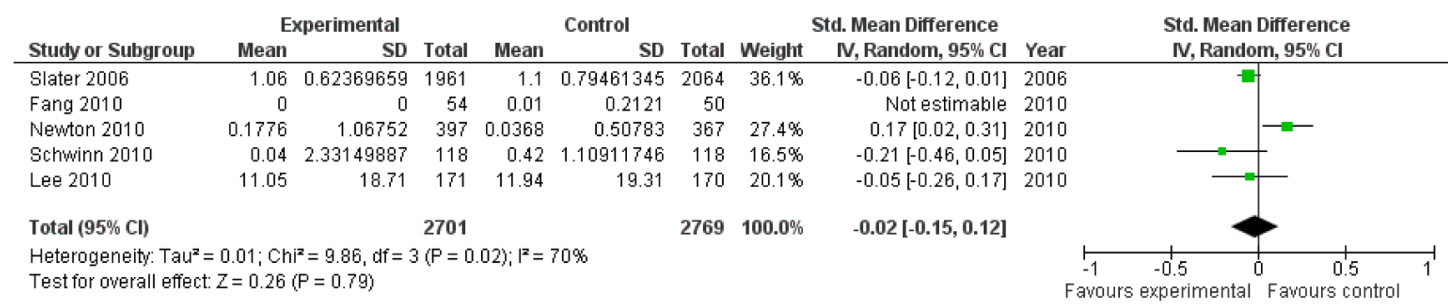

B

Intention to use drugs

\begin{tabular}{|c|c|c|c|c|c|c|c|c|c|c|c|}
\hline \multirow[b]{2}{*}{ Study or Subgroup } & \multicolumn{3}{|c|}{ Experimental } & \multicolumn{3}{|c|}{ Control } & \multicolumn{3}{|c|}{ Std. Mean Difference } & \multirow{2}{*}{\multicolumn{2}{|c|}{$\begin{array}{l}\text { Std. Mean Difference } \\
\text { IV, Fixed, } 95 \% \mathrm{Cl}\end{array}$}} \\
\hline & Mean & SD & Total & Mean & SD & Total & Weight & IV, Fixed, $95 \%$ CI & Year & & \\
\hline Polansky 1999 & 1 & 2.13 & 78 & 1.06 & 1.97 & 26 & $6.9 \%$ & $-0.03[-0.47,0.42]$ & 1999 & & \\
\hline Polansky 1999 & 0.74 & 2.18 & 78 & 1.06 & 1.97 & 26 & $6.8 \%$ & $-0.15[-0.59,0.30]$ & 1999 & & \\
\hline Polansky 1999 & 0.76 & 1.99 & 78 & 1.06 & 1.97 & 26 & $6.8 \%$ & $-0.15[-0.59,0.29]$ & 1999 & & \\
\hline Yzer 2003 & 1.56 & 0.93 & 63 & 1.52 & 0.89 & 48 & $9.6 \%$ & $0.04[-0.33,0.42]$ & 2003 & & \\
\hline Yzer 2003 & 1.58 & 1.04 & 71 & 1.52 & 0.89 & 48 & $10.1 \%$ & $0.06[-0.31,0.43]$ & 2003 & & \\
\hline Yzer 2003 & 1.62 & 0.98 & 141 & 1.52 & 0.89 & 48 & $12.6 \%$ & $0.10[-0.22,0.43]$ & 2003 & & \\
\hline Zhao 2006 & 1.47 & 0.93 & 208 & 1.65 & 1.08 & 227 & $38.1 \%$ & $-0.18[-0.37,0.01]$ & 2006 & $\longrightarrow-$ & \\
\hline Fang 2010 & 2.11 & 15.0644 & 54 & 3.7 & 23.9709 & 50 & $9.1 \%$ & $-0.08[-0.46,0.31]$ & 2010 & & \\
\hline Total $(95 \% \mathrm{Cl})$ & & & 771 & & & 499 & $100.0 \%$ & $-0.07[-0.19,0.04]$ & & & \\
\hline $\begin{array}{l}\text { Heterogeneity: } \mathrm{Chi}^{2}= \\
\text { Test for owerall effect }\end{array}$ & $\begin{array}{l}3.45, \mathrm{df}= \\
Z=1.25\end{array}$ & $\begin{array}{l}=7(P=0 . \\
(P=0.21)\end{array}$ & 84); $1^{2}=$ & & & & & & & experimental & Favours \\
\hline
\end{tabular}

Figure 2 Pooling of randomised controlled trials. Adapted from a previous publication. ${ }^{4}$ 
Table 3 Main findings for use or intention to use illicit drugs

\begin{tabular}{|c|c|c|c|c|c|c|c|c|}
\hline Pooling & Outcome & Design & References & Subgroups & $\begin{array}{l}\text { Number of } \\
\text { subjects exp } \\
\text { vs ctrl† }\end{array}$ & $\begin{array}{l}\text { Effect } \\
\text { measure }\end{array}$ & $\begin{array}{l}\text { Effect size }(95 \% \mathrm{Cl}) \\
\text { or effect direction ( } \mathrm{p} \text {-value) } \ddagger\end{array}$ & $\begin{array}{l}\text { Heterogeneity } \\
\text { p-valueף }\end{array}$ \\
\hline \multirow[t]{6}{*}{$\begin{array}{l}\text { Pooled } \\
\text { analyses }\end{array}$} & Use of illicit drugs & $\mathrm{RCT}$ & $\begin{array}{l}\text { Slater et al 2006; } ;^{10} \text { Fang et al } \\
2010 ;{ }^{18} \text { Newton et al } 2010 ;{ }^{11} \\
\text { Schwinn et al } 2010 ;{ }^{19} \text { Lee et al } \\
2010^{28}\end{array}$ & - & 2701 vs 2769 & $\begin{array}{l}\text { SMD, random } \\
\text { effects }\end{array}$ & $-0.02(-0.15$ to 0.12$)$ & $0.020^{*}$ \\
\hline & Intention to use illicit drugs & $\mathrm{RCT}$ & $\begin{array}{l}\text { Polansky et al } 1999 ;{ }^{25} \text { Yzer } \\
\text { et al 2003; }{ }^{26} \text { Zhao et al 2006; }{ }^{27} \\
\text { Fang et al } 2010^{18}\end{array}$ & - & 771 vs 499 & SMD, fixed effects & $-0.07(-0.19$ to 0.04$)$ & 0.840 \\
\hline & Past-month use of & 4 ITS and $1 \mathrm{CBA}$ & Meth Project studies ${ }^{12-16}$ & age $12-17$ & 14865 vs 7497 & OR, random effects & $1.16(0.83$ to 1.61$)$ & - \\
\hline & methamphetamine & & & age $18-24$ & 347 vs 632 & OR, random effects & 1.63 (0.70 to 3.79$)$ & - \\
\hline & Past-year use of & 4 ITS and 1 CBA & Meth Project studies ${ }^{12-16}$ & age $12-17$ & 17105 vs 7497 & OR, random effects & $0.59(0.43 \text { to } 0.81)^{\star \star}$ & - \\
\hline & methamphetamine & & & age $18-24$ & 1039 vs 632 & OR, random effects & 0.70 (0.34 to 1.45$)$ & - \\
\hline \multirow[t]{11}{*}{$\begin{array}{l}\text { Single } \\
\text { studies }\end{array}$} & $\begin{array}{l}\text { Lifetime, past } 90 \text {-day, or } \\
\text { past-30-day use of }\end{array}$ & $\begin{array}{l}\text { RCT } \\
\text { (community-media) }\end{array}$ & Slater et al $2011^{21}$ & - & NA (3236) & OR, random effects & $0.60(0.38 \text { to } 0.94)^{\star}$ & - \\
\hline & marijuana & $\begin{array}{l}\text { Cohort } \\
\text { (mass-media) }\end{array}$ & & - & & OR, random effects & $0.26(0.19 \text { to } 0.35)^{\star \star \star}$ & - \\
\hline & Past-year use of marijuana & Cohort & Hornik $2006^{22}$ & - & NA (3529) & OR, fixed effects & $1.21(1.19 \text { to } 1.65)^{\star}$ & - \\
\hline & Intention to use marijuana & & & - & NA (2915) & OR, fixed effects & $0.89(0.79 \text { to } 1.00)^{\S}$ & - \\
\hline & $\begin{array}{l}\text { Past } 12 \text {-month episodes of } \\
\text { cannabis intoxication }\end{array}$ & Cohort & $\begin{array}{l}\text { Scheier and Grenard et al } \\
2010^{23}\end{array}$ & age $13-14$ & NA (2515) & $\begin{array}{l}\text { mean difference, } \\
\text { SEM }\end{array}$ & -0.022 & - \\
\hline & & & & age $15-18$ & & $\begin{array}{l}\text { mean difference, } \\
\text { SEM }\end{array}$ & $0.144^{*}$ & - \\
\hline & Past 30-day use of & ITS & Palmgreen et al $2001^{24}$ & Fayette & NA (3174) & test for slope & $\downarrow(p=0.001)$ & - \\
\hline & $\begin{array}{l}\text { marijuana among } \\
\text { high-sensation seekers }\end{array}$ & & & $\begin{array}{l}\text { Knox, first } \\
\text { campaign }\end{array}$ & NA (3197) & test for slope & $\downarrow(p=0.001)$ & \\
\hline & & & & $\begin{array}{l}\text { Knox, second } \\
\text { campaign }\end{array}$ & & test for slope & $\downarrow(p=0.002)$ & - \\
\hline & $\begin{array}{l}\text { Past 30-day use of } \\
\text { marijuana (girls, 8th grade) }\end{array}$ & ITS & Carpenter and Pechmann $2011^{2}$ & - & NA (130 245) & OR, fixed effects & $0.67(0.52 \text { to } 0.87)^{\star \star}$ & - \\
\hline & $\begin{array}{l}\text { Frequency of use of } 10 \\
\text { types of drugs }\end{array}$ & CBA & Miller et al $2000^{20}$ & - & 567 vs 431 & $\begin{array}{l}\text { mean difference, } \\
\text { ANOVA }\end{array}$ & $\begin{array}{l}\text { for LSD: } \uparrow(p<0.001) \\
\text { for marijuana, cocaine, } \\
\text { amphetamine, and heroin: 'no } \\
\text { longer significant' differences }\end{array}$ & - \\
\hline
\end{tabular}

${ }^{8} \mathrm{p}<0.10{ }^{*} \mathrm{p}<0.05^{* *} \mathrm{p}<0.01{ }^{* \star *} \mathrm{p}<0.001$.

†NA=breakdowns of students exposed to the interventions were not available. Number of analysed subjects is between brackets.

$\ddagger$ Whenever the effect size was not reported, $\downarrow=$ decreased use or intention to use, and $\uparrow=$ increased use or intention to use.

१Heterogeneity test for meta-analyses of RCTs.

ANOVA, analysis of variance; CBA, controlled before and after; Cohort, prospective cohort; ITS, interrupted time-series; RCT, randomised controlled trial; SEM, structural equation modelling; SMD,

standardised mean difference. 
A

Past-month Use of Methamphetamines
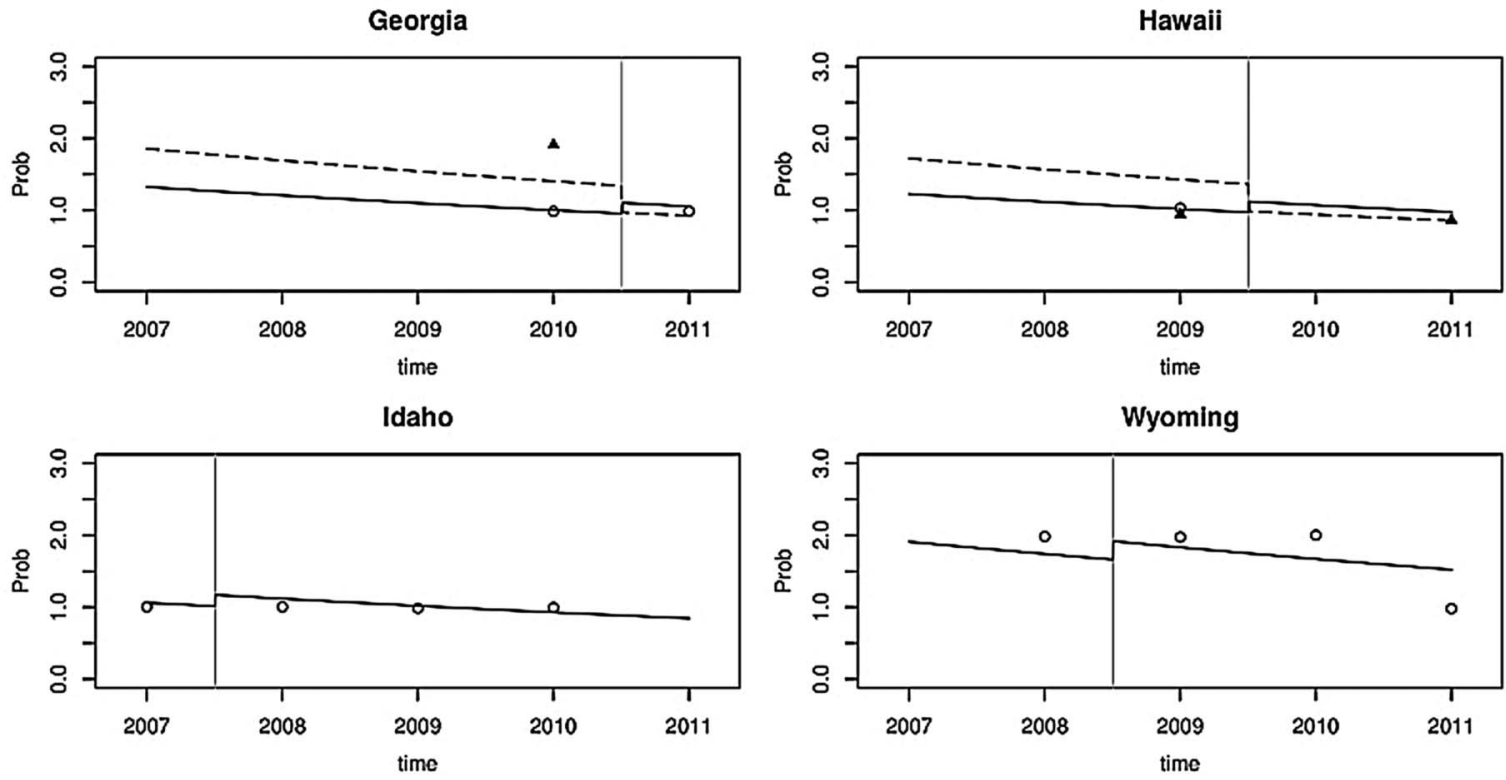

Observed probabilities
Teens $\quad$ Y Young adults

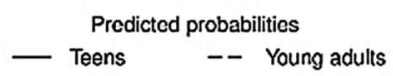

B

Past-year Use of Methamphetamines
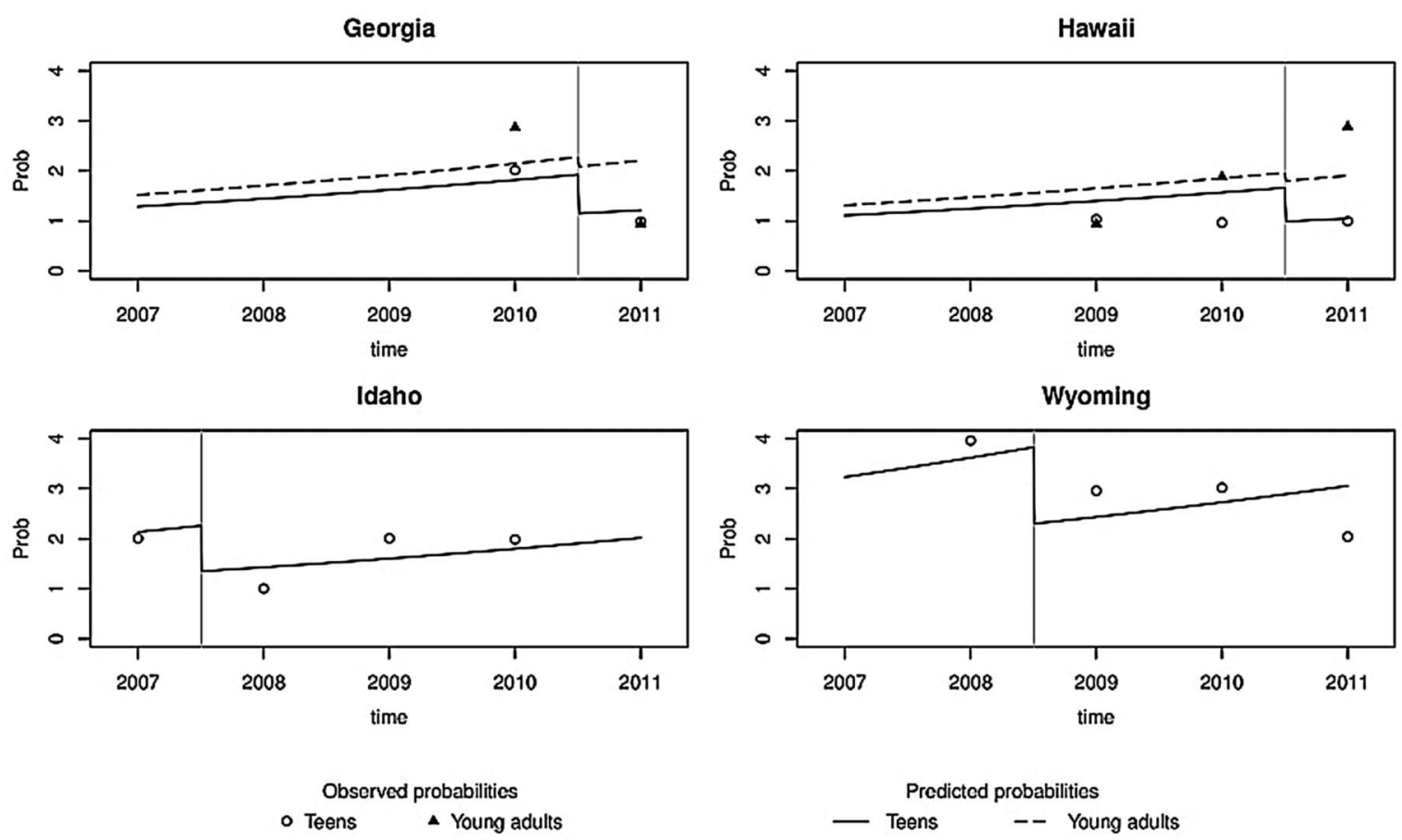

Figure 3 Pooling of the meth project interrupted time-series studies: predicted and observed probabilities. Adapted from a previous publication. ${ }^{4}$

Intention to use drugs

Experimental studies

In one meta-analysis of four randomised controlled studies involving 1270 participants, there was no evidence of an effect $(\mathrm{p}=0.21)$ of media campaigns in changing intention to use drugs (SMD $-0.07 ; 95 \%$ CI
-0.19 to 0.04 ; figure 2 and table 3$).{ }^{18}{ }^{25-27}$ There was no evidence $(\mathrm{p}=0.840)$ of heterogeneity across studies.

\section{Field studies}

One study ( $\mathrm{n}=2915)$ found some evidence $(\mathrm{p}=0.053)$ of a reduction in intentions to use marijuana (OR 0.89; 
$95 \%$ CI 0.79 to 1.00 ; table 3 ) for the first version of the ONDCP's media campaign. ${ }^{22}$

\section{DISCUSSION}

Mass-media campaigns are commonly used throughout the world to tackle a broad array of preventable risk factors or injuries. Such campaigns are seldom evaluated, thus making it difficult to inform policymakers regarding their effectiveness and sustainability. In this panorama of overall uncertainty, mass-media campaigns tackling tobacco and traffic accidents are noteworthy exceptions as they have been evaluated more frequently and have shown some evidence for benefit. ${ }^{29}$ In our attempt to summarise evidence on the effectiveness of mass-media campaigns targeting illicit drugs, we included 19 studies evaluating a number of heterogeneous interventions. We grouped interventions according to whether they were evaluated with studies conducted in experimental settings in which participants were aware of being exposed to media interventions, or were assessed with studies carried out in a field environment which are more likely to show the real-life effects of large national media campaigns, but are also more prone to risk of bias.

Findings appear to vary considerably according to the type of intervention and study design. Pooled analyses of eight interventions evaluated in an experimental setting provided no evidence of beneficial effects for use or intention to use illicit drugs, an indicator of possible future behaviour. $^{3031}$ Four interventions evaluated with eight field studies revealed some evidence of beneficial effects: (1) the revamped campaign by the Office of National Drug Control Policy (ONDCP) called Above the Influence, which was found effective in one study and effective among eighth-grade girls in another study; (2) the Be Under Your Own Influence mediacommunity intervention; (3) the Meth Project campaign, which was found effective on past-year methamphetamine use, although only among adolescents aged 12-17 years; and (4) the US televised antimarijuana campaigns broadcast in Fayette County (Lexington), Kentucky and in Knox County (Knoxville), Tennessee, which were found to be effective on highsensation seekers. Two mass media campaigns showed clear iatrogenic effects, most notably, the first version of the ONDCP's media campaign My Anti Drug, which was evaluated by two studies and was found to increase use of marijuana. An adverse effect was also found for a mediacommunity intervention evaluated by a CBA study which provided evidence of increased frequency of LSD use.

No characteristic emerged clearly as a core feature of successful or unsuccessful campaigns, either regarding their explicit or implicit theoretical background or their communication strategies. However, it is worth noting that two out of the four interventions providing evidence of effectiveness, the ONDCP's Above the Influence national campaign and the Be Under Your Own
Influence media-community intervention promoted non-use of drugs as a way to support the goals of autonomy and achievement of competence, both of which have been conceptualised as innate psychological needs that persist over the lifespan. ${ }^{21}$ Among the interventions which provided evidence of harmful effects, the first version of the ONDCP's media campaign My Anti Drug was based on a social marketing approach which emphasised resistance skills, self-efficacy, normative education and negative consequences of drug use. ${ }^{32}$ These mediators are suspected to have increased the perception of prevalence of drug use in the target population. ${ }^{33}$

An important reason for the weak evidence obtained by this review is the large variation in mass-media intervention type and study design. Similar interventions were often evaluated with different study designs while different interventions were sometimes evaluated with the same study design. Pooled analyses could thus be undertaken only for a few similar interventions evaluated with the same study design, and such small sets of pooled studies did not allow sensitivity analyses to be carried out. We did not set any time or language constraints to our search, accepted all types of controlled study designs and obtained unpublished data by establishing direct contact with the authors of the original papers. Unfortunately, owing to the paucity and inconsistency of available evidence, we cannot draw general conclusions as to whether media campaigns are effective in preventing the use or the intention to use illicit drugs. This observation is in line with the findings of similar reviews that used more restrictive inclusion criteria. $^{29} 34$

The evidence base accrued so far on media campaigns targeting illicit drugs allows us to make at least two remarks. First, such campaigns can be evaluated-a fact that is often questioned in several parts of the world-and properly conducted evaluation studies can provide benefits to both research and practice. Second, in the worst-case scenario, media campaigns can be both ineffective and harmful. Contrary to common belief, antidrug media campaigns may be damaging and their dissemination is ethically unacceptable without a prior assessment of their effects. ${ }^{35}$ New campaigns should be implemented in the framework of rigorous evaluation studies, ideally in field settings with cohort or ITS study designs. A better understanding of which media interventions work best is likely to result in a more effective prevention of drug use and increased efficiency in the management of public resources.

\section{Author affiliations}

${ }^{1}$ Department of Translational Medicine, Università del Piemonte Orientale, Novara, Italy

${ }^{2}$ School of Public Health, University of Torino, Torino, Italy

${ }^{3}$ Consequences, Responses and Best Practices Unit, European Monitoring Centre for Drugs and Drug Addiction, Lisbon, Portugal

${ }^{4}$ Department of Medical Statistics, London School of Hygiene \& Tropical Medicine, London, UK 
Acknowledgements The authors are grateful to the Cochrane Drug and Alcohol Group for their support in publishing the Cochrane review from which this paper has been extracted. ${ }^{4}$ They thank Gregor Burkhart and V Anna Gyarmathy for their input to the drafting of the protocol for this review, and Marie-Christine Ashby and Fozia Hamid for carefully proofreading the manuscript. The authors are grateful to Ling Fang, John Horan, Nicola Newton, Philip Palmgreen, Joan Polansky, Michael Slater, Jennifer Stagnaro, Violeta Taneva and Marco Yzer for their useful advice and for providing their studies' unpublished data whenever possible.

Contributors EA structured and drafted the paper. MF and FF conceived the systematic review from which the paper originates and overviewed the inclusion of studies and their methodological assessment. MF and EA selected the studies for inclusion. $E A$ and $A B$ extracted the data from the studies and contributed to the writing of the review. EA contacted study authors. $E A$ and $A B$ did the meta-analysis of randomised controlled trials. $A G$ and EA conducted the meta-analysis of interrupted time-series studies. All authors regularly discussed each step of the review process and participated equally in each decision regarding the studies and the analysis. They also revised the paper and read and approved the final version of this manuscript.

Funding AG was supported through a Methodology Research fellowship awarded by Medical Research Council-UK (grant ID G1002296). The EMCDDA provided IT equipment and journal access for EA during his traineeship, funding for purchasing of papers not included in standard subscriptions, and funding for the open access publication of this paper.

Competing interests None declared.

Provenance and peer review Not commissioned; externally peer reviewed.

Data sharing statement Data and statistical code used for pooled analyses are available and can be requested from the corresponding author (EA, elias. allara@med.unipmn.it).

Open Access This is an Open Access article distributed in accordance with the Creative Commons Attribution Non Commercial (CC BY-NC 4.0) license, which permits others to distribute, remix, adapt, build upon this work noncommercially, and license their derivative works on different terms, provided the original work is properly cited and the use is non-commercial. See: http:// creativecommons.org/licenses/by-nc/4.0/

\section{REFERENCES}

1. Sumnall HR, Bellis MA. Can health campaigns make people ill? The iatrogenic potential of population-based cannabis prevention. $J$ Epidemiol Community Health 2007;61:930-1.

2. Carpenter CS, Pechmann C. Exposure to the Above the Influence antidrug advertisements and adolescent marijuana use in the United States, 2006-2008. Am J Public Health 2011;101:948-54.

3. Moher D, Liberati A, Tetzlaff J, et al. Preferred reporting items for systematic reviews and meta-analyses: the PRISMA statement. BMJ 2009;339:b2535.

4. Ferri M, Allara E, Bo A, et al. Media campaigns for the prevention of illicit drug use in young people. Cochrane Database Syst Rev 2013;6:CD009287.

5. Brinn MP, Carson KV, Esterman AJ, et al. Mass media interventions for preventing smoking in young people. Cochrane Database Syst Rev 2010;(11):CD001006.

6. Higgins J, Green S. Cochrane handbook for systematic reviews of interventions. 2011. http://www.cochrane-handbook.org

7. Scottish Intercollegiate Guidelines Network. Critical appraisal: notes and checklists. 2010. http://www.sign.ac.uk/methodology/checklists. html (accessed 12 Sep 2010).

8. Cochrane Effective Practice and Organisation of Care Group. Draft EPOC Methods Paper Including Interrupted Time Series (ITS) Designs in a EPOC Review. 1998.

9. Review Manager (RevMan) [Computer program]. Version 5.3. Copenhagen: The Nordic Cochrane Centre, The Cochrane Collaboration, 2014

10. Slater MD, Kelly KJ, Edwards RW, et al. Combining in-school and community-based media efforts: reducing marijuana and alcohol uptake among younger adolescents. Health Educ Res 2006;21:157-67.

11. Newton NC, Teesson M, Vogl LE, et al. Internet-based prevention for alcohol and cannabis use: final results of the Climate Schools course. Addiction 2010;105:749-59.

12. The Meth Project. Colorado Meth: Use \& Attitudes Survey 2011. 2011.

13. The Meth Project. Georgia Meth: Use \& Attitudes Survey 2011 2011.

14. The Meth Project. Idaho Meth: Use \& Attitudes Survey 2010. 2010.

15. The Meth Project. Hawaii Meth: Use \& Attitudes Survey 2011. 2011.

16. The Meth Project. Wyoming Meth: Use \& Attitudes Survey 2011. 2011.

17. Gilmour S, Degenhardt L, Hall W, et al. Using intervention time series analyses to assess the effects of imperfectly identifiable natural events: a general method and example. BMC Med Res Methodol 2006;6:16.

18. Fang L, Schinke SP, Cole KC. Preventing substance use among early Asian-American adolescent girls: initial evaluation of a web-based, mother-daughter program. J Adolesc Health 2010;47:529-32.

19. Schwinn TM, Schinke SP, Di Noia J. Preventing drug abuse among adolescent girls: outcome data from an internet-based intervention. Prev Sci 2010;11:24-32.

20. Miller WR, Toscova RT, Miller JH, et al. A theory-based motivational approach for reducing alcohol/drug problems in college. Health Educ Behav 2000;27:744-59.

21. Slater MD, Kelly KJ, Lawrence FR, et al. Assessing media campaigns linking marijuana non-use with autonomy and aspirations: 'Be Under Your Own Influence' and ONDCP's 'Above the Influence'. Prev Sci 2011;12:12-22.

22. Hornik R. Personal Influence and the Effects of the National Youth Anti-Drug Media Campaign. Ann Am Acad Pol Soc Sci 2006;608:282-300.

23. Scheier LM, Grenard JL. Influence of a nationwide social marketing campaign on adolescent drug use. J Health Commun 2010;15:240-71.

24. Palmgreen $P$, Donohew L, Lorch EP, et al. Television campaigns and adolescent marijuana use: tests of sensation seeking targeting. Am J Public Health 2001;91:292-6.

25. Polansky JM, Buki LP, Horan JJ, et al. The effectiveness of substance abuse prevention videotapes with Mexican American adolescents. Hisp J Behav Sci 1999;21:186-98.

26. Yzer MC, Cappella JN, Fishbein M, et al. The effectiveness of gateway communications in anti-marijuana campaigns. J Health Commun 2003;8:129-43.

27. Zhao X, Sayeed S, Cappella J, et al. Targeting norm-related beliefs about marijuana use in an adolescent population. Health Commun 2006;19:187-96.

28. Lee CM, Neighbors C, Kilmer JR, et al. A brief, web-based personalized feedback selective intervention for college student marijuana use: a randomized clinical trial. Psychol Addict Behav 2010;24:265-73.

29. Wakefield MA, Loken B, Hornik RC. Use of mass media campaigns to change health behaviour. Lancet 2010;376:1261-71.

30. Litchfield R, White K. Young adults' willingness and intentions to use amphetamines: an application of the theory of reasoned action. E-J Appl Psychol 2006;2:45-51.

31. Olds RS, Thombs DL, Tomasek JR. Relations between normative beliefs and initiation intentions toward cigarette, alcohol and marijuana. J Adolesc Health 2005;37:75.

32. Hornik R, Jacobsohn L, Orwin R, et al. Effects of the National Youth Anti-Drug Media Campaign on youths. Am J Public Health 2008:98:2229-36.

33. Hornik R, Jacobsohn L. The best laid plans: disappointments of the National Youth Anti-Drug Media Campaign. LDI Issue Brief 2008;14:1-4.

34. Werb D, Mills EJ, Debeck K, et al. The effectiveness of anti-illicit-drug public-service announcements: a systematic review and meta-analysis. J Epidemiol Community Health 2011;65:834-40.

35. Faggiano F, Giannotta F, Allara E. Strengthening prevention science to ensure effectiveness of intervention in practice: setting up an international agenda. In: Sloboda Z, Petras H, eds. Defining prevention science. Boston, MA: Springer US, 2014:597-615

36. Faggiano F, Allara E, Giannotta F, et al. Europe needs a central, transparent, and evidence-based approval process for behavioura prevention interventions. PLoS Med 2014;11:e1001740. 